\title{
Pandangan Gereja Masehi Injili di Halmahera (GMIH) Wilayah Pelayanan Tobelo Terhadap Dunia Bisnis
}

\author{
Ricardo F. Nanuru ${ }^{1}$ \\ ricardonanuru632@,gmail.com; ricardo@uniera.ac.id \\ Lomas Beatris Limpong ${ }^{2}$ \\ lomaslimpong@yahoo.com
}

\begin{abstract}
Background of this study is the church statement that empowerment is essential to deal with the impact of globalization on the welfare of the people but in reality is not implemented properly. The Church has the financial resources but very few are used for empowerment programs. This fact indicates that the finances for the church is a "sacred thing", so it can't be used to finance empowerment programs, especially business programs. The purpose of this study was to investigate the relationship between negative outlook of GMIH Service Area Tobelo about the business world with the actions that do not want to get involved in it. This study uses quantitative and qualitative methods. Data collection techniques used were questionnaires, indepth interviews, and observation. Data analysis technique is a combination of quantitative analysis (Pearson Product Moment) and qualitative analysis (triangulation of data, methodology, and theory). The results of this study indicate that there is a relationship between a negative view of the church (members GMIH) about the business world with their actions that do not want to get involved in it. Values obtained from the analysis is 0.79 were categorized as high relationships.
\end{abstract}

Keywords: church, resources, empowerment, business.

\footnotetext{
${ }^{1}$ Staf Pengajar pada Program Studi PGSD Fakultas Keguruan dan IImu Pendidikan (FKIP), Universitas Halmahera.

${ }^{2}$ Staf Pengajar pada Program Studi Manajemen Fakultas IImu Sosial dan Humaniora (FISHUM), Universitas Halmahera.
} 


\section{Pendahuluan}

Dunia bisnis dewasa ini sangat menjanjikan prospek yang cerah. Tidak sedikit orang berkecimpung dan terlibat dalam dunia bisnis. Mulai dari yang berskala mikro sampai makro, dari yang legal sampai yang illegal, dari pelaku bisnis perorangan sampai kelompok. Banyak orang serta kelompok yang terlibat di dalam dunia bisnis oleh karena dunia tersebut benar-benar menyediakan ruang yang sangat luas untuk berkarya, meningkatkan kesejahteraan bahkan mendapatkan keuntungan. Namun, tak jarang dunia bisnis diidentikan dengan suatu keadaan yang penuh dengan kecurangan, yang di dalamnya terdapat berbagai praktek ketidakadilan, penyelewengan, penipuan dan lain sebagainya (Hill, 1998: 1). Pendapat ini ada benarnya juga jika ditinjau dari segi visi bisnis yang semata-mata mengejar laba besar tanpa peduli dengan lingkungan, yang mengeksploitasi tenaga manusia tanpa memperhatikan kesehatan, yang memakai dan menghalalkan segala cara termasuk KKN, yang menjual barang dengan kualitas rendah, yang dengan segala cara mematikan usaha orang lain yang mungkin menjadi kompetitor dan lain sebagainya (Parapak, 1999: 318). Hal mana secara langsung mempengaruhi opini publik tentang dunia bisnis itu sendiri termasuk pelaku-pelaku bisnis yang terlibat di dalamnya sebagai dunia dan orang-orang yang perlu dijauhi, perlu dihindari bahkan dicap tabu dan sangat negatif. Tak jarang orang Kristen bahkan lembaga gereja mengambil sikap yang demikian pula. Apabila ada upaya pengembangan ekonomi jemaat dalam hubungan dengan bisnis, serentak dianggap sebagai sesuatu yang negatif.

Keadaan ini semakin bertambah parah oleh karena bisnis terkadang dilihat dalam sisi yang lain yaitu semata-mata soal duniawi. Buktinya, jarang sekali kita mendengar percakapan bisnis yang terkait dengan soal iman. Apakah ini pertanda bisnis tidak terkait dengan soal iman? (Parapak, 1999: 317). Atau mungkinkah pandangan antara agama dan ekonomi masih terbatas pada teori isolasi yang melihat agama dan ekonomi sebagai dua ruangan yang terpisah dan terisolasi serta bekerja menurut mekanismenya masingmasing atau teori konfrontasi yang di dalamnya terjadi pertentangan antara agama dan ekonomi dan keduanya diyakini tidak bisa co-exist tanpa terjadi saling membantai atau berperang, dan belum menanjak pada teori kolusi yang melihat adanya hubungan yang kolusif antara agama dan ekonomi? (Darmaputra, 1999: 130-146). Sementara pada sisi lain pelaku bisnis dalam kipranya akan berhadapan terus-menerus dengan berbagai keputusan yang berdimensi etis dan moral, mulai dari menentukan bisnis apa yang akan dilaksanakan; apakah boleh berbisnis dalam bidang yang ada kaitannya dengan judi? Yang ada hubungannya dengan komersialisasi yang terang-terangan berdampak negatif terhadap kesehatan dan eksploitasi wanita? Bagaimana menetapkan sasaran keuntungan, harga dan lain-lain. Berapakah keuntungan yang wajar? Bagaimana memenangkan tender? Bagaimana mengatur pembukuan dan pembayaran pajak? Pertanyaanpertanyaan ini menegaskan bahwa seluruh proses bisnis sarat dengan dimensi etika dan moral yang sangat terkait pula dengan persoalan iman. (Parapak, 1999: 319). Dengan demikian tak dapat dihindari bahwa pembicaraan tentang bisnis dan iman Kristen merupakan tugas penting dan menarik untuk distudikan dari saat ke saat. 
Sebuah penelitian terhadap keprihatinan sosial gereja injili, khususnya terhadap masalah kemiskinan di dua kota besar Jakarta dan Bandung, mengungkapkan bahwa sekitar 20-27\% dari seluruh responden telah mengalokasi dana untuk urusan sosial dan itu dilakukan 1-4 kali per tahun, dan kemungkinan hal itu dilakukan secara seremonial, maksudnya dilakukan pada saat perayaan-perayaan gerejawi seperti Paskah, Natal atau acara tertentu. Informasi ini mengisyaratkan betapa kurangnya tanggapan komunitas orang percaya dalam gereja terhadap masalah kemiskinan (Mamahit, 2005: 253).

Pendapat Mamahit di atas, tentu saja mengindikasikan bahwa gereja belum terlalu peduli terhadap masalahmasalah sosial yang diakibatkan oleh dampak globalisasi, diantaranya masalah kemiskinan. Globalisasi tentu saja mempunya dampak yang besar, baik secara positif maupun negatif, sehingga gereja sudah sepantasnya perlu mempersiapkan diri untuk menghadapinya. Gereja sebagai lembaga yang mengatur hidup umat kristiani harus lebih giat dalam berefleksi tentang makna kehadirannya dalam dunia.

Sebagai kegiatan berteologi, usahausaha dalam melakukan refleksi bagi kehadiran gereja di tanah air adalah kebutuhan yang tak terhindarkan. Paling tidak dalam proses-proses refleksi ini, kita akan menemukan model/pola kehadiran gereja selama ini, dan sekaligus menjadi titik tolak bagi kehadiran gereja yang lebih relevan dalam menjawab konteks pelayanan gereja yang terus berubah. Dalam kaitan ini, maka proses refleksi terhadap kehadiran gereja tidak boleh selesai, ataupun berhenti pada satu waktu (Robert, 2004: 46).
Lebih lanjut, Robert (2004: 49) dalam membahas pemikiran Eka Darmaputera menyatakan bahwa "gereja adalah alat, bukan tujuan". Hal ini berarti bahwa hakikat keberadaan gereja adalah bahwa gereja haruslah menjadi alat yang harus digunakan untuk mensejaterahkan manusia. Gereja dihadirkan Allah di dunia untuk ikut berpartisipasi dalam misi Allah kepada dunia ini. Dunia dalam seluruh dimensinya, baik ekonomi, budaya, bahkan politik yang selama ini dilihat sebagai bidang yang 'kotor'.

Berdasarkan pendapat Darmaputera seperti dikaji Robert di atas, maka dapat dikemukakan bahwa gereja sebagai utusan Allah di dunia sudah sepantasnya berkecimpung dalam setiap bidang kehidupan, termasuk ekonomika dan bisnis. Kegiatan bisnis harus direfleksikan gereja sebagai bagian yang harus dimasuki gereja tanpa memandangnya sebagai sesuatu yang kotor, yang tidak perlu disentuh, tetapi harus dipandang sebagai bagian dari pola pelayanan dan pengembangan gereja yang dapat memberdayakan dan mensejaterahkan umat di dalamnya.

Pertanyaannya sekarang adalah apakah pandangan negatif terhadap dunia bisnis turut mempengaruhi warga jemaat kristen yang bernaung di bawah Gereja Masehi Injili di Halmahera (GMIH), sehingga mereka cenderung tidak mau memakai uang (dana) gereja untuk berbisnis? Berdasarkan studi awal yang dilakukan ternyata bahwa, banyak gereja yang bernaung di bawah GMIH termasuk gereja dalam Wilayah Pelayanan Tobelo tidak pernah terjun dalam dunia bisnis sehingga dana yang digalang gereja jarang bahkan tidak pernah dipakai gereja untuk berbisnis. Padahal sumber daya manusia gereja sangat mendukung untuk melakukan kegiatan bisnis ini. Hal ini 
merupakan suatu hal yang sangat ironis karena ketika gereja berbicara tentang pemberdayaan ekonomi jemaat, ternyata bahwa gereja sebagai lembaga tidak pernah merogoh sakunya untuk berkarya dan mengkaryakan anggotanya dalam dunia bisnis. Padahal gereja memiliki kemampuan sumberdaya dan dana untuk berkecimpung dalam dunia tersebut.

Mengingat pemberdayaan ekonomi jemaat merupakan suatu hal yang sementara hangat dibicarakan, baik di tingkat sinode maupun di tingkat jemaat maka sudah sepantasnya jika salah satu agenda penting yaitu bisnis harus dilakoni gereja. Namun kenyataan yang terjadi justru hal ini hanya menjadi semacam wacana tanpa tindakan nyata dari pihak gereja sebagai lembaga.

Berkaitan dengan permasalahan yang dikemukakan di atas, maka tujuan dari penelitian ini adalah Menguraikan hubungan antara pandangan negatif Gereja (anggota GMIH) di Wilayah Pelayanan Tobelo terhadap dunia bisnis dengan tindakannya yang tidak mau berkecimpung di dunia bisnis.

\section{Metode Penelitian}

\section{a) Lokasi Penelitian}

Lokasi penelitian ditentukan secara sengaja (purposive) yaitu organisasi atau lembaga gereja (anggota GMIH) yang berada dalam Wilayah Pelayanan Tobelo yang berjumlah 20 jemaat. Pemilihan lokasi tersebut didasarkan atas pertimbangan bahwa lembaga-lembaga gereja di wilayah ini memiliki kondisi sumberdaya manusia dan sumberdaya keuangan yang cukup kuat atau memadai untuk dijadikan sampel penelitian. b) Teknik Pengumpulan Data

Teknik pengumpulan data yang dipakai dalam penelitian ini adalah kuisioner. Kuisioner merupakan teknik pengumpulan data yang dilakukan dengan cara memberi seperangkat pertanyaan atau pernyataan tertulis kepada responden untuk dijawab. Kuisioner merupakan teknik pengumpulan data yang efisien bila peneliti tahu dengan pasti variabel yang akan diukur dan tahu apa yang bisa diharapkan dari responden (Sugiyono, 2007:142). Selain kuisioner yang dipakai, data dalam penelitian ini juga diperoleh dengan teknik wawancara mendalam serta observasi terhadap lembagalembaga gereja di Wilayah Pelayanan Tobelo.

\section{c) Teknik Analisa Data}

Data yang berhasil dikumpulkan, dianalisa secara kuantitatif dan kualitatif. Analisa kuantitatif dilakukan dengan bantuan tabel frekuensi, kemudian untuk menguji hubungan antar variabel digunakan analisis statistik "Pearson Product Moment" dengan langkah-langkah sebagai berikut:

1. Mengidentifikasi secara operasional konsep yang akan diukur.

2. Merekapitulasi jawaban/tanggapan responden terhadap variabel bebas (X) dan variabel terikat (Y).

3. Membuat tabel perolehan nilai responden terhadap masing-masing variabel.

4. Menghitung hubungan antara kedua variabel dengan membuat tabel kerja korelasi produck moment yang selanjutnya diolah dengan rumus korelasi Pearson Produck Moment sebagai berikut:

$$
r x y=\frac{n(\Sigma x y)-(\Sigma x)(\Sigma y)}{\sqrt{\left\{n\left(\Sigma x^{2}\right)-(\Sigma x)^{2}\right)\left\{n\left(\Sigma y^{2}\right)-(\Sigma y)^{2}\right\}}}
$$

Dimana

rxy $\quad=$ Koefisien korelasi 


$$
\begin{array}{rlrl}
\mathrm{x} & = & \text { Skor dalam distribusi } \\
& & \text { variabel } \mathrm{x} \\
\mathrm{y} & = & \text { Skor dalam distribusi } \\
& & \text { variabel } \mathrm{y} \\
\mathrm{n} & = & \text { Banyaknya pasangan skor } \\
& \mathrm{x} \text { dan y (subyek) }
\end{array}
$$

5. Selanjutnya sebagai pedoman untuk memberikan interpretasi koefisien korelasi digunakan ukuran seperti yang tertera dalam tabel berikut:

Tabel 1. Pedoman Koefisien Korelasi Koefisien hubungan (r) Penafsiran

$$
r \leq 0,00
$$

Tidak ada hubungan

$0,01<\mathrm{r} \leq 0,20$

Hubungan sangat rendah

$0,21<\mathrm{r} \leq 0,40$

Hubungan rendah

$0,41<\mathrm{r} \leq 0,60$

Hubungan sedang

$0,61<\mathrm{r} \leq 0,80$

Hubungan tinggi

$0,81<\mathrm{r} \leq 1,00$

Hubungan sangat tinggi

Sumber: Sugiyono, 2007:184

Data yang diperoleh dari setiap responden akan diberi nilai/skor sebagai berikut:

Jawabam "a" akan diberi skor nilai " 3 " Jawabam "b" akan diberi skor nilai "2" Jawabam "c" akan diberi skor nilai "1"

Analisa kualitatif dilakukan dengan teknik trianggulasi (data, metodologi, dan teori) terhadap masalah pandangan negatif gereja terhadap dunia bisnis dan faktor-faktor yang mempengaruhinya

\section{Hasil dan Pembahasan}

Penelitian ini berusaha untuk mengukur dua variabel yaitu:

1) Variabel Bebas (X) : Pandangan negatif Gereja (anggota GMIH) Wilayah Pelayanan Tobelo terhadap dunia bisnis.

2) Variabel Terikat $(Y)$ : Tindakan Gereja (anggota GMIH) Wilayah Pelayanan Tobelo yang tidak berkecimpung dalam dunia bisnis
Kedua variabel ini dapat didefenisikan sebagai berikut:

Yang dimaksud dengan pandangan negatif Gereja (anggota GMIH) Wilayah Pelayanan Tobelo terhadap dunia bisnis adalah keseluruhan pola pikir atau world view atau mind set dari para pemuka gereja (baik pendeta, majelis jemaat) maupun jemaat pada umumnya yang pada dasarnya menganggap dunia bisnis sebagai bagian yang terpisahkan atau lepas dari tugas dan tanggung jawab pelayanan gereja. Indikator yang dipakai untuk mengukur variabel ini adalah:

1. Dunia bisnis adalah hal duniawi yang kotor.

2. Dunia bisnis tidak berkaitan dengan ajaran iman Kristen.

3. Dunia bisnis penuh dengan kecurangan, penipuan, KKN, ketidakadilan, dll.

4. Dana gereja adalah suci sehingga tidak bisa dipakai di dunia bisnis.

5. Gereja adalah lembaga pelayanan yang dikhususkan untuk kerohanian.

Yang dimaksud dengan tindakan Gereja (anggota GMIH) Wilayah Pelayanan Tobelo yang tidak berkecimpung dalam dunia bisnis adalah keseluruhan sikap dan atau tindakan bahkan langkah-langkah proteksi dari pemuka gereja (pendeta, majelis jemaat) maupun jemaat pada umumnya yang tidak mau mempergunakan nama, dana maupun sumber daya manusia gereja dalam dunia bisnis. Indikator yang dipakai untuk mengukur variabel ini adalah:

1. Tidak mengagendakan soal dunia bisnis dalam pertemuan-pertemuan resmi gerejawi (Sidang Jemaat, Rapat Sidi Jemaat)

2. Tidak menggunakan mimbar gereja maupun ibadah lainnya dalam kaitan dengan pembicaraan seputar dunia bisnis.

3. Tidak menggunakan dana dan SDM gereja secara khusus dalam dunia bisnis.

4. Tidak memiliki Bidang Khusus dalam organisasi gereja yang bergerak dalam rangka mengembangkan kegiatan dunia bisnis di jemaat.

5. Tidak memiliki badan usaha khusus yang bergerak di dunia bisnis $(\mathrm{CV}$, 
Toko, Koperasi simpan pinjam, dan sejenisnya).

\section{Analisa Data}

Untuk menguji serta mengetahui hubungan antara variabel $\mathrm{x}$ dan variabel $\mathrm{y}$, maka hasil penelitian dianalisa sebagai berikut.

a) Hasil rekapitulasi tanggapan responden terhadap variabel bebas (x): "pandangan negatif Gereja (anggota GMIH) Wilayah Pelayanan Tobelo terhadap dunia bisnis."

Hasil rekapitulasi tanggapan responden terhadap indikator-indikator variabel bebas dapat dilihat pada tabel berikut ini.

Tabel 2. Rekapitulasi Tanggapan Responden

Terhadap Indikator Variabel Bebas

\begin{tabular}{|c|c|c|c|}
\hline No & Indikator & $\mathrm{F}$ & $\%$ \\
\hline 1 & $\begin{array}{l}\text { Dunia bisnis adalah hal } \\
\text { duniawi yang "kotor" } \\
\text { a) Ya } \\
\text { b) Tidak } \\
\text { c) Tidak tahu }\end{array}$ & $\begin{array}{c}35 \\
3 \\
2\end{array}$ & $\begin{array}{c}87,5 \\
7,5 \\
5\end{array}$ \\
\hline 2 & $\begin{array}{llr}\text { Dunia bisnis } & \text { tidak } \\
\text { berkaitan dengan ajaran } \\
\text { Iman Kristen } \\
\text { a) Ya } \\
\text { b) Tidak } \\
\text { c) Tidak tahu }\end{array}$ & $\begin{array}{c}31 \\
3 \\
6\end{array}$ & $\begin{array}{c}77,5 \\
7,5 \\
15\end{array}$ \\
\hline 3 & $\begin{array}{l}\text { Dunia bisnis penuh dengan } \\
\text { kecurangan, penipuan, } \\
\text { KKN, ketidakadilan, dan } \\
\text { sebagainya. } \\
\text { a) Ya } \\
\text { b) Tidak } \\
\text { c) Tidak tahu }\end{array}$ & $\begin{array}{c}35 \\
0 \\
5\end{array}$ & $\begin{array}{c}87,5 \\
0 \\
12,5\end{array}$ \\
\hline 4 & $\begin{array}{l}\text { Dana gereja adalah suci } \\
\text { sehingga tidak bisa dipakai } \\
\text { di dunia bisnis. } \\
\text { a) Ya } \\
\text { b) Tidak } \\
\text { c) Tidak tahu }\end{array}$ & $\begin{array}{c}36 \\
3 \\
1\end{array}$ & $\begin{array}{l}90 \\
7,5 \\
2,5\end{array}$ \\
\hline 5 & $\begin{array}{lr}\text { Gereja adalah } & \text { lembaga } \\
\text { pelayanan } & \text { yang } \\
\text { dikhususkan } & \text { untuk } \\
\text { kerohanian. } & \\
\text { a) Ya } & \\
\text { b) Tidak } & \\
\text { c) Tidak tahu } & \end{array}$ & $\begin{array}{c}39 \\
0 \\
1\end{array}$ & $\begin{array}{c}97,5 \\
0 \\
2,5\end{array}$ \\
\hline
\end{tabular}

Sumber: Hasil penelitian
Dari hasil tanggapan responden terhadap indikator variabel bebas di atas, kemudian disebarkan untuk mengetahui perolehan nilai dari setiap responden dalam rangka keperluan analisis. Perolehan nilai tersebut dapat dilihat dalam tabel berikut.

Tabel 3. Perolehan Nilai Responden pada Variabel Bebas

\begin{tabular}{|c|c|c|c|c|c|c|c|}
\hline \multirow[t]{2}{*}{ No } & \multicolumn{5}{|c|}{ Indikator } & \multirow[t]{2}{*}{ Total } & \multirow[t]{2}{*}{ Ket. } \\
\hline & $\mathrm{X} 1$ & $\mathrm{X} 2$ & $\mathrm{X} 3$ & $X 4$ & $\times 5$ & & \\
\hline 1 & 3 & 1 & 3 & 3 & 3 & 13 & \multirow{39}{*}{$\begin{array}{l}N= \\
40\end{array}$} \\
\hline 2 & 3 & 3 & 3 & 3 & 3 & 15 & \\
\hline 3 & 3 & 3 & 3 & 3 & 3 & 15 & \\
\hline 4 & 3 & 3 & 3 & 3 & 3 & 15 & \\
\hline 5 & 3 & 3 & 3 & 3 & 3 & 15 & \\
\hline 6 & 3 & 3 & 3 & 3 & 3 & 15 & \\
\hline 7 & 3 & 3 & 3 & 3 & 3 & 15 & \\
\hline 8 & 3 & 3 & 3 & 3 & 3 & 15 & \\
\hline 9 & 3 & 3 & 3 & 3 & 3 & 15 & \\
\hline 10 & 3 & 3 & 3 & 3 & 3 & 15 & \\
\hline 11 & 2 & 1 & 1 & 3 & 3 & 10 & \\
\hline 12 & 2 & 2 & 1 & 2 & 3 & 10 & \\
\hline 13 & 3 & 1 & 3 & 3 & 3 & 13 & \\
\hline 14 & 3 & 3 & 3 & 3 & 3 & 15 & \\
\hline 15 & 3 & 3 & 3 & 3 & 3 & 15 & \\
\hline 16 & 3 & 3 & 3 & 3 & 3 & 15 & \\
\hline 17 & 3 & 3 & 3 & 3 & 3 & 15 & \\
\hline 18 & 3 & 3 & 3 & 3 & 3 & 15 & \\
\hline 19 & 3 & 1 & 3 & 3 & 3 & 13 & \\
\hline 20 & 3 & 3 & 3 & 3 & 3 & 15 & \\
\hline 21 & 3 & 3 & 3 & 3 & 3 & 15 & \\
\hline 22 & 3 & 3 & 3 & 3 & 3 & 15 & \\
\hline 23 & 1 & 1 & 1 & 2 & 2 & 7 & \\
\hline 24 & 3 & 3 & 3 & 3 & 3 & 15 & \\
\hline 25 & 3 & 3 & 3 & 3 & 3 & 15 & \\
\hline 26 & 3 & 3 & 3 & 3 & 3 & 15 & \\
\hline 27 & 2 & 2 & 1 & 2 & 1 & 8 & \\
\hline 28 & 1 & 2 & 1 & 2 & 3 & 9 & \\
\hline 29 & 3 & 3 & 3 & 3 & 3 & 15 & \\
\hline 30 & 3 & 3 & 3 & 3 & 3 & 15 & \\
\hline 31 & 3 & 1 & 3 & 3 & 3 & 13 & \\
\hline 32 & 3 & 3 & 3 & 3 & 3 & 15 & \\
\hline 33 & 3 & 3 & 3 & 3 & 3 & 15 & \\
\hline 34 & 1 & 1 & 1 & 1 & 3 & 7 & \\
\hline 35 & 3 & 3 & 3 & 3 & 3 & 15 & \\
\hline 36 & 3 & 3 & 3 & 3 & 3 & 15 & \\
\hline 37 & 3 & 3 & 3 & 3 & 3 & 15 & \\
\hline 38 & 3 & 3 & 3 & 3 & 3 & 15 & \\
\hline 39 & 3 & 3 & 3 & 3 & 3 & 15 & \\
\hline
\end{tabular}




\begin{tabular}{|l|l|l|l|l|l|l|l|}
\hline 40 & 3 & 3 & 3 & 3 & 3 & 15 & \\
\hline & & & & & & & \\
\hline
\end{tabular}

Sumber: Hasil penelitian

b) Hasil rekapitulasi tanggapan responden terhadap variabel terikat $(\mathrm{y})$ : tindakan Gereja (anggota GMIH) Wilayah Pelayanan Tobelo yang tidak berkecimpung dalam dunia bisnis.

Hasil rekapitulasi jawaban responden terhadap indikator-indikator variabel terikat dapat dilihat pada tabel berikut.

Tabel 4 Rekapitulasi Tanggapan Responden Terhadap Indikator Variabel Terikat

\begin{tabular}{|c|c|c|c|}
\hline No & Indikator & $\mathrm{F}$ & $\%$ \\
\hline 1 & $\begin{array}{l}\text { Apakah pertemuan resmi } \\
\text { gereja (Rapat Sidi Jemaat) } \\
\text { mengagendakan } \\
\text { pembicaraan soal bisnis? } \\
\text { a) Tidak } \\
\text { b) Ya } \\
\text { c) Tidak tahu }\end{array}$ & $\begin{array}{c}35 \\
3 \\
2\end{array}$ & $\begin{array}{c}87,5 \\
7,5 \\
5\end{array}$ \\
\hline 2 & $\begin{array}{lr}\text { Apakah } & \text { gereja } \\
\text { menggunakan } & \text { mimbar } \\
\text { ibadah minggu maupun } & \\
\text { ibadah lainnya dalam kaitan } \\
\text { dengan pembicaraan seputar } \\
\text { dunia bisnis? } \\
\text { a) Tidak } \\
\text { b) Ya } \\
\text { c) Tidak tahu }\end{array}$ & $\begin{array}{c}32 \\
3 \\
5\end{array}$ & $\begin{array}{c}80 \\
7,5 \\
12,5\end{array}$ \\
\hline 3 & $\begin{array}{l}\text { Apakah } r \text { gereja } \\
\text { menggunakan dana dan } \\
\text { SDM-nya secara khusus } \\
\text { dalam dunia bisnis? } \\
\text { a) Tidak } \\
\text { b) Ya } \\
\text { c) Tidak tahu }\end{array}$ & $\begin{array}{c}34 \\
0 \\
6\end{array}$ & $\begin{array}{c}85 \\
0 \\
15\end{array}$ \\
\hline 4 & $\begin{array}{lrr}\text { Apakah gereja } & \text { memiliki } \\
\text { Bidang Khusus } & \text { dalam } \\
\text { organisasi yang } & \text { bergerak } \\
\text { dalam } & \text { rangka } \\
\text { mengembangkan } & \text { kegiatan } \\
\text { bisnis di jemaat? } & \\
\text { a) Tidak } \\
\text { b) Ya } \\
\text { c) Tidak tahu }\end{array}$ & $\begin{array}{c}37 \\
3 \\
0\end{array}$ & $\begin{array}{c}92,5 \\
7,5 \\
0\end{array}$ \\
\hline 5 & $\begin{array}{l}\text { Apakah gereja memiliki } \\
\text { badan usaha khusus yang } \\
\text { bergerak di dunia bisnis } \\
\text { (CV, Toko, Koperasi } \\
\text { Simpan Pinjam, dan } \\
\text { sejenisnya)? }\end{array}$ & & \\
\hline
\end{tabular}

a) Tidak

b) $\mathrm{Ya}$

c) Tidak tahu

Sumber: Hasil penelitian

Dari hasil tanggapan responden terhadap indikator variabel terikat di atas, kemudian disebarkan untuk mengetahui perolehan nilai dari setiap responden dalam rangka keperluan analisis. Perolehan nilai tersebut dapat dilihat dalam tabel berikut.

Tabel 5 Perolehan Nilai Responden pada Variabel Terikat

\begin{tabular}{|c|c|c|c|c|c|c|c|}
\hline \multirow[t]{2}{*}{ No } & \multicolumn{5}{|c|}{ Indikator } & \multirow[t]{2}{*}{ Total } & \multirow[t]{2}{*}{ Ket. } \\
\hline & Y1 & Y2 & Y3 & Y4 & Y5 & & \\
\hline 1 & 3 & 1 & 3 & 3 & 3 & 13 & \multirow{35}{*}{$\begin{array}{l}N= \\
40\end{array}$} \\
\hline 2 & 3 & 3 & 3 & 3 & 3 & 15 & \\
\hline 3 & 3 & 3 & 3 & 3 & 3 & 15 & \\
\hline 4 & 3 & 3 & 3 & 3 & 3 & 15 & \\
\hline 5 & 3 & 3 & 3 & 3 & 3 & 15 & \\
\hline 6 & 3 & 3 & 3 & 3 & 3 & 15 & \\
\hline 7 & 3 & 3 & 3 & 3 & 3 & 15 & \\
\hline 8 & 3 & 3 & 3 & 3 & 3 & 15 & \\
\hline 9 & 3 & 3 & 3 & 3 & 3 & 15 & \\
\hline 10 & 3 & 3 & 3 & 3 & 3 & 15 & \\
\hline 11 & 2 & 1 & 1 & 3 & 3 & 10 & \\
\hline 12 & 2 & 2 & 1 & 2 & 3 & 10 & \\
\hline 13 & 3 & 1 & 3 & 3 & 3 & 13 & \\
\hline 14 & 3 & 3 & 3 & 3 & 3 & 15 & \\
\hline 15 & 3 & 3 & 3 & 3 & 3 & 15 & \\
\hline 16 & 3 & 3 & 3 & 3 & 3 & 15 & \\
\hline 17 & 3 & 3 & 3 & 3 & 3 & 15 & \\
\hline 18 & 3 & 3 & 3 & 3 & 3 & 15 & \\
\hline 19 & 3 & 1 & 1 & 3 & 3 & 11 & \\
\hline 20 & 3 & 3 & 3 & 3 & 3 & 15 & \\
\hline 21 & 3 & 3 & 3 & 3 & 3 & 15 & \\
\hline 22 & 3 & 3 & 3 & 3 & 3 & 15 & \\
\hline 23 & 1 & 2 & 3 & 2 & 1 & 9 & \\
\hline 24 & 3 & 3 & 3 & 3 & 3 & 15 & \\
\hline 25 & 3 & 3 & 3 & 3 & 3 & 15 & \\
\hline 26 & 3 & 3 & 3 & 3 & 3 & 15 & \\
\hline 27 & 2 & 2 & 1 & 2 & 1 & 8 & \\
\hline 28 & 1 & 2 & 1 & 2 & 3 & 9 & \\
\hline 29 & 3 & 3 & 3 & 3 & 3 & 15 & \\
\hline 30 & 3 & 3 & 3 & 3 & 3 & 15 & \\
\hline 31 & 3 & 3 & 3 & 3 & 3 & 15 & \\
\hline 32 & 3 & 3 & 3 & 3 & 3 & 15 & \\
\hline 33 & 3 & 3 & 3 & 3 & 3 & 15 & \\
\hline 34 & 1 & 1 & 1 & 3 & 1 & 7 & \\
\hline 35 & 3 & 3 & 3 & 3 & 3 & 15 & \\
\hline
\end{tabular}




\begin{tabular}{|l|l|l|l|l|l|l|}
\hline 36 & 3 & 3 & 3 & 3 & 3 & 15 \\
\hline 37 & 3 & 3 & 3 & 3 & 3 & 15 \\
\hline 38 & 3 & 3 & 3 & 3 & 3 & 15 \\
\hline 39 & 3 & 3 & 3 & 3 & 3 & 15 \\
\hline 40 & 3 & 3 & 3 & 3 & 3 & 15 \\
\hline & & & & & & \\
\hline
\end{tabular}

Sumber: Hasil penelitian

c. Hubungan antara variabel bebas (x) "pandangan negatif Gereja (anggota GMIH) Wilayah Pelayanan Tobelo terhadap dunia bisnis" dengan variabel terikat (y) "tindakan Gereja (anggota GMIH) Wilayah Pelayanan Tobelo yang tidak berkecimpung dalam dunia bisnis."

Telah dikemukakan sebelumnya bahwa untuk menguji hubungan antara variabel $\mathrm{x}$ dan y maka akan digunakan rumus statistik "product moment". Untuk mencari hubungan kedua variabel tersebut, maka perolehan nilai masing-masing responden dimasukkan ke dalam tabel kerja korelasi yang dapat dilihat di bawah ini.

Tabel 6 Tabel Kerja Korelasi Product Moment

\begin{tabular}{|c|c|c|c|c|c|}
\hline No & $\mathrm{X}$ & $\mathrm{Y}$ & $\mathrm{X}^{2}$ & $\mathrm{Y}^{2}$ & $\mathrm{XY}$ \\
\hline 1 & 13 & 13 & 169 & 169 & 169 \\
\hline 2 & 15 & 15 & 225 & 225 & 225 \\
\hline 3 & 15 & 15 & 225 & 225 & 225 \\
\hline 4 & 15 & 15 & 225 & 225 & 225 \\
\hline 5 & 15 & 15 & 225 & 225 & 225 \\
\hline 6 & 15 & 15 & 225 & 225 & 225 \\
\hline 7 & 15 & 15 & 225 & 225 & 225 \\
\hline 8 & 15 & 15 & 225 & 225 & 225 \\
\hline 9 & 15 & 15 & 225 & 225 & 225 \\
\hline 10 & 15 & 15 & 225 & 225 & 225 \\
\hline 11 & 10 & 10 & 100 & 100 & 100 \\
\hline 12 & 10 & 10 & 100 & 100 & 100 \\
\hline 13 & 13 & 13 & 169 & 169 & 169 \\
\hline 14 & 15 & 15 & 225 & 225 & 225 \\
\hline 15 & 15 & 15 & 225 & 225 & 225 \\
\hline 16 & 15 & 15 & 225 & 225 & 225 \\
\hline 17 & 15 & 15 & 225 & 225 & 225 \\
\hline 18 & 15 & 15 & 225 & 225 & 225 \\
\hline 19 & 13 & 11 & 225 & 121 & 143 \\
\hline 20 & 15 & 15 & 225 & 225 & 225 \\
\hline 21 & 15 & 15 & 225 & 225 & 225 \\
\hline 22 & 15 & 15 & 225 & 225 & 225 \\
\hline 23 & 7 & 9 & 49 & 81 & 63 \\
\hline 24 & 15 & 15 & 225 & 225 & 225 \\
\hline & & & & & \\
\hline & & & \\
\hline 15 & & & \\
\hline 15 & 15 & 225 \\
\hline
\end{tabular}

\begin{tabular}{|c|c|c|c|c|c|}
\hline 25 & 15 & 15 & 225 & 225 & 225 \\
\hline 26 & 15 & 15 & 225 & 225 & 225 \\
\hline 27 & 8 & 8 & 64 & 64 & 64 \\
\hline 28 & 9 & 9 & 81 & 81 & 81 \\
\hline 29 & 15 & 15 & 225 & 225 & 225 \\
\hline 30 & 15 & 15 & 225 & 225 & 225 \\
\hline 31 & 13 & 15 & 225 & 225 & 195 \\
\hline 32 & 15 & 15 & 225 & 225 & 225 \\
\hline 33 & 15 & 15 & 225 & 225 & 225 \\
\hline 34 & 7 & 7 & 49 & 49 & 49 \\
\hline 35 & 15 & 15 & 225 & 225 & 225 \\
\hline 36 & 15 & 15 & 225 & 225 & 225 \\
\hline 37 & 15 & 15 & 225 & 225 & 225 \\
\hline 38 & 15 & 15 & 225 & 225 & 225 \\
\hline 39 & 15 & 15 & 225 & 225 & 225 \\
\hline 40 & 15 & 15 & 225 & 225 & 225 \\
\hline & $\mathbf{5 5 3}$ & $\mathbf{5 5 5}$ & $\mathbf{7 9 8 1}$ & $\mathbf{7 9 0 9}$ & $\mathbf{7 8 8 3}$ \\
\hline
\end{tabular}

Sumber: Hasil penelitian

Berdasarkan nilai kedua variabel yang tergambar pada tabel kerja korelasi di atas, maka akan dihitung korelasi antara variabel $\mathrm{x}$ dan variabel y dengan memasukkan nilainilai yang ada pada tabel kerja korelasi ke dalam rumus di bawah ini:

$$
\begin{aligned}
& r x y=\frac{n\left(\sum x y\right)-\left(\sum x\right)\left(\sum y\right)}{\sqrt{\mid\left\{n\left(\sum^{x^{2}}\right)-\left(\sum^{x}\right)^{2}\right\}\left\{n\left(\sum y^{2}\right)-\left(\sum y\right)^{2}\right\}}} \\
& =\frac{40(7883)-(553)(555)}{\sqrt{\left\{40(7981)-(553)^{2}\right\}\left\{40(7909)-(555)^{2}\right\}}} \\
& =\frac{315320-306915}{\sqrt{\{319240-305809\}\{316360-308025\}}} \\
& =\frac{8405}{\sqrt{\{13431\}\{8335\}}}=\frac{8405}{\sqrt{111947385}} \\
& =\frac{8405}{10580,51}=0,79
\end{aligned}
$$

Dari hasil perhitungan di atas, menunjukkan bahwa hubungan antara pandangan negatif gereja (anggota GMIH) Wilayah Pelayanan Tobelo terhadap dunia bisnis dengan tindakannya yang tidak berkecimpung dalam dunia bisnis adalah sebesar 0,79 atau masuk dalam kriteria hubungan tinggi. 


\section{Interpretasi}

Berdasarkan pada hasil perhitungan korelasi dari kedua variabel di atas, menunjukkan bahwa kedua variabel yaitu pandangan negatif gereja (GMIH) di Wilayah Pelayanan Tobelo terhadap dunia bisnis dengan tindakannya yang tidak berkecimpung dalam dunia bisnis memiliki hubungan atau korelasi. Hubungan atau korelasi ini masuk dalam kategori atau kriteria hubungan yang tinggi yaitu 0,79 $(0,61<\mathrm{r} \leq 0,80)$.

Hubungan atau korelasi ini pada dasarnya merupakan kenyataan yang terjadi pada warga gereja, dimana pandangan atau wawasan berpikir umat cenderung sangat negatif terhadap dunia bisnis, sehingga mempengaruhi tindakan mereka yang tidak mau mempergunakan dana dan sumberdaya manusia secara khusus untuk dipergunakan dalam dunia bisnis. Hal ini tentu saja bermasalah jika ditelusuri, dimana keuangan gereja yang begitu kuat hanya terpendam dalam perbendaharaan gereja, padahal di kalangan umat membutuhkan topangan dana untuk kegiatan-kegiatan wirausaha.

Hal ini tentu saja membutuhkan perubahan paradigma berpikir di kalangan para pemimpin umat yang akan berdampak pada perubahan paradigma di kalangan umat. Berdasarkan hasil wawancara mendalam dengan beberapa pendeta dan penatua jemaat, ditemukan bahwa pandangan ini sudah berakar lama di dalam jemaat sehingga mereka hanya mengikuti apa yang dikehendaki jemaat tanpa berusaha mengkritisinya. Ketika ditanya tentang sumber pandangan tersebut, para pendeta dan penatua jemaat hanya menitikberatkan pada tradisi yang telah diikuti sejak dahulu tanpa ada pemahaman teologis yang mendalam.

Hal di atas tentu saja berbeda dengan beberapa pendapat ahli dalam landasan teori seperti dikemukakan pada telaah pustaka di awal laporan penelitian ini. Gereja sebagai utusan Allah di dunia sudah sepantasnya berkecimpung dalam setiap bidang kehidupan, termasuk ekonomika dan bisnis. Kegiatan bisnis harus direfleksikan gereja sebagai bagian yang harus dimasuki gereja tanpa memandangnya sebagai sesuatu yang kotor, yang tidak perlu disentuh, tetapi harus dipandang sebagai bagian dari pola pelayanan dan pengembangan gereja yang dapat memberdayakan dan mensejaterahkan umat di dalamnya.

Bisnis sepantasnya dipandang gereja sebagai bagian yang tak terpisahkan dari perencanaan pengembangan dan pemberdayaan umat, sehingga sumberdaya baik sumberdaya manusia maupun sumberdaya keuangan gereja dapat dimanfaatkan demi tercapainya kesejateraan umat. Selama ini yang terjadi di Gereja Masehi Injili di Halmahera (GMIH) adalah kegiatan bisnis dengan menggunakan sumberdaya gereja dianggap sebagai sesuatu yang 'kotor' sehingga cenderung dijauhi, bahkan tidak pernah masuk dalam agendaagenda persidangan, baik persidangan di tingkat jemaat, maupun ditingkat sinodal. Padahal, jika ditelusuri, GMIH adalah gereja yang bertolak dari ajaran Calvinis yang justru menyetujui penggunaan sumberdaya keuangan gereja demi menolong orang miskin, atau demi pengembangan ekonomi masyarakat.

Sumberdaya keuangan gereja sudah sepantasnya digunakan untuk mendatangkan kesejahteraan. Tetapi sumberdaya keuangan gereja ini haruslah dikelola secara profesional dengan mengedepankan aspek pelayanan bagi orang miskin dan pelaku usaha yang membutuhkan bantuan atau sokongan dana demi mengembangkan usaha atau produksi yang nantinya bermuara pada menguatnya ekonomi umat. Dengan kata lain dapat dikemukakan bahwa sumberdaya keuangan gereja bukanlah sesuatu yang 'kudus' yang harus dijaga untuk beredar di kalangan 'terbatas' atau kalangan 'sendiri', tetapi sepantasnya dipakai untuk menunjang kegiatan produksi umat demi penguatan pemberdayaan ekonomi yang menghasilkan kesejahteraan. 


\section{Penutup}

Berdasarkan hasil penelitian yang dilakukan, didapati bahwa ada hubungan antara pandangan negatif gereja (anggota GMIH) Wilayah Pelayanan Tobelo terhadap dunia bisnis dengan tindakannya yang tidak berkecimpung dalam dunia bisnis. Hubungan itu adalah sebesar 0,79 atau masuk dalam kriteria hubungan tinggi.

Berdasarkan hal di atas, maka sudah sepantasnya jika Badan Pekerja Harian Sinode GMIH disarankan agar lebih menggali pengetahuan seputar paradigma berpikir umat, dalam hal ini yang terkait dengan pandangan dan penggunaan dana dan sumberdaya manusia gereja. Sejalan dengan itu, maka para pemimpin umat (Pendeta dan Penatua) agar lebih menambah wawasan tentang landasan teologis yang dapat melegitimasi kegiatan ekonomika dan bisnis di dalam gereja sehingga ke depan dana dan sumberdaya manusia gereja dapat dipakai secara khusus dalam dunia bisnis yang berdampak pada peningkatan kesejahteraan umat.

\section{Daftar Pustaka}

\section{Buku}

Darmaputera Eka, 1999, Altar dan Pasar, Struktur Relasi Agama dan Ekonomi, dalam Sularso Sopater dkk (peny), Gereja dan Kontekstualisasi, Jakarta: PSH.
Hill Alexander, 1998, Etika Bisnis Kristiani, Yogyakarta: Kanisius.

Parapak Jonathan, 1999, Iman Kristen dan Peranannya dalam Usaha Bisnis dalam Ferdi Suleeman dkk, (peny), Bergumul dalam Pengharapan, Jakarta: Gunung Mulia.

Sugiyono, 2007, Metode Penelitian Kuantitatif, Kualitatif, $R \& D$, Bandung: Alfabeta.

\section{Jurnal}

Mamahit Ferry, Y, Globalisasi, Gereja Injili dan Transformasi Sosial, Jurnal VERITAS 6/2 (Oktober 2005), halaman. 253-275.

Robert Reinal, Menjadi Gereja yang Fungsional: Arah Kehadiran Gereja dalam Konteks Indonesia Menurut Eka Darmaputera, Jurnal STT Intim Makassar, Edisi No. 6 - Semester Genap 2004. 